University of Nebraska - Lincoln

DigitalCommons@University of Nebraska - Lincoln

Faculty Publications from the Harold W. Manter Laboratory of Parasitology

2-1-2005

\title{
Bolivian Ectoparasites: A New Species of Laelapine Mite (Acari: Parasitiformes, Laelapidae) from the Rodent Neacomys spinosus
}

Donald Gettinger

University of Nebraska-Lincoln, donaldgettinger@gmail.com

Scott Lyell Gardner

University of Nebraska - Lincoln, slg@unl.edu

Follow this and additional works at: https://digitalcommons.unl.edu/parasitologyfacpubs

Part of the Parasitology Commons

Gettinger, Donald and Gardner, Scott Lyell, "Bolivian Ectoparasites: A New Species of Laelapine Mite (Acari: Parasitiformes, Laelapidae) from the Rodent Neacomys spinosus" (2005). Faculty Publications from the Harold W. Manter Laboratory of Parasitology. 40.

https://digitalcommons.unl.edu/parasitologyfacpubs/40

This Article is brought to you for free and open access by the Parasitology, Harold W. Manter Laboratory of at DigitalCommons@University of Nebraska - Lincoln. It has been accepted for inclusion in Faculty Publications from the Harold W. Manter Laboratory of Parasitology by an authorized administrator of DigitalCommons@University of Nebraska - Lincoln. 


\title{
BOLIVIAN ECTOPARASITES: A NEW SPECIES OF LAELAPINE MITE (ACARI: PARASITIFORMES, LAELAPIDAE) FROM THE RODENT NEACOMYS SPINOSUS
}

\author{
Donald Gettinger and Scott L. Gardner \\ Harold W. Manter Laboratory of Parasitology, University of Nebraska-Lincoln, Lincoln, Nebraska 68588-0514. e-mail: donaldg@alltel.net
}

\begin{abstract}
Laelaps neacomydis $\mathrm{n}$. sp. is described from the pelage of the rodent Neacomys spinosus collected in Bolivia. Collection records from northern Brazil, southeastern Peru, and central Bolivia indicate its wide distribution across Amazonas associated with rodents of the genus Neacomys. The formal taxonomic description and illustrations are derived from the adults (female and male). Two larger species of laelapine mites, Gigantolaelaps intermedius and L. boultoni, infest the same hosts at the same localities.
\end{abstract}

In an extensive survey of small mammals and ectoparasites in Venezuela, Furman (1972) identified laelapine mites associated with the oryzomyine rodent, Neacomys tenuipes Thomas, under the name Laelaps pilifer Tipton. He recognized a great range of morphological variation in the Venezuelan $L$. pilifer, "varying from forms agreeing well with the original figures and description to forms with dorsal plate setae either minute in size or very long and coarse." Furman briefly described 3 morphological forms of $L$. pilifer in Venezuela; form B, with very long dorsal setation was most frequently collected from $N$. tenuipes. Subsequently, in our studies of material from recent surveys of neotropical small mammals and their ectoparasites, we have confirmed the strong association between this laelapine mite and hosts of Neacomys. Furman's "form B" was collected exclusively from $N$. tenuipes in an intensive survey (Gettinger et al., 2005) near Manaus, Amazonas, from N. spinosus (Thomas) in eastern Peru and Bolivia (D. Gettinger and S. Gardner, unpubl. data). Because this mite is broadly distributed, host specific, and clearly morphologically distinct, it is formally named and described here, on the basis of the female and male.

\section{MATERIALS AND METHODS}

While conducting a large-scale survey of mammals and their parasites from throughout Bolivia (Gardner and Campbell, 1992; Anderson, 1997), oryzomyine rodents of the genus Neacomys were captured primarily in lowland tropical rain forests (Bosque Amazonico) and on the forested slopes of the eastern Andes (Yungas). Live-trapped small mammals were removed from traps, placed into plastic bags, and anaesthetized with ether or chloroform. Ectoparasites were then removed, primarily by brushing the animal within the plastic bag, and stored in $70 \%$ ethyl alcohol (for more information on field sampling methods; see Gardner, 1996). After arrival in the laboratory, representative specimens were mounted individually in Hoyer medium, ringed with Glyptal, and measured with a stage-calibrated ocular micrometer. All measurements are in micrometers $(\mu \mathrm{m})$; when referring to more than 1 specimen; measurements are given as the mean, followed by the range in parentheses. Drawings were made with the aid of a drawing tube. We use the system of mite setal nomenclature developed by Lindquist and Evans (1965) and follow Wilson and Reeder (1993) and Anderson (1997) for mammalogy.

\section{DESCRIPTION}

\section{Laelaps neacomydis $\mathrm{n}$. sp.}

Female (Figs. 1-2): Dorsal shield entire, oblong, with prominent shoulders; reticulate sculpturing throughout, broadest about midlevel, with 39 pairs of strong, simple setae, plus an

Received 29 December 2003; revised 26 April 2004; accepted 26 April 2004 unpaired accessory seta located centrally between setae J3 and $\mathrm{J} 4$; j-J and $\mathrm{z}-\mathrm{Z}$ series complete; central podonotal setae strong and long, j5 reaching well posterior to base of z5; J5 long, more than half the length of Z5; glands and pores as illustrated. Unarmed dorsolateral idiosoma (Fig. 1) with 9 pairs of submarginal and 6 pairs of marginal setae.

Ventrally, sternal shield slightly wider than long, broadest at posterolateral angles; anterior margin flat between first sternal setae; posterior margin slightly concave; surface sculpturing reticulate-lineate extending into presternal region, reticulatepunctate medially; first 2 pairs of sternal pores on the shield, elongate-lyriform; sternal setae strong, increasing in length from St1 to St3, St1 extends beyond level of second set of lyriform pores; third pair of tiny lyriform pores on unarmed integument medial to strongly sclerotized metasternal shields, which bear strong fourth pair of sternal setae. Epigynial shield rounded posteriorly and expanded laterally posterior to long setiform epigynial setae; greatest shield width at level of first of 3 pairs of posterior accessory setae; posterior margin convex. Metapodal shields small, oval, lightly sclerotized and granular; anal shield subtriangular, reticulate on anterior and lateral margins; paranal setae short, about $1 / 2$ length of postanal seta; cribrum with 3 rows of denticles, extending laterally to point slightly anterior to insertion of postanal seta. Unarmed opisthogaster with 5 pairs of strong, simple setae. Peritreme extends over anterior half of coxa II, with peritrematic shield extending posterior to stigma.

Epistome simple, membranous. Chelicerae thick and chelatedentate; arthrodial processes well-developed; moveable digit with 2 teeth and a strongly hooked tip; fixed digit with 1 small tooth, and a long, inflated, sickle-shaped pilus dentilis. Ventrally, tritosternum with unornamented base and lightly fimbriate laciniae; gnathosomatic chaetotaxy normal; inner pair of hypostomal setae longest but not reaching to insertion of gnathosomal (palpcoxal) setae; outer hypostomal and anterior hypostomal setae shorter than gnathosomal setae. Deutosternum with 6 or 7 transverse rows of denticles; corniculi strongly scleotized and hornlike; internal malae with long dorsolateral fringe; labrum extends anterior to corniculi. Pedipalps with 5 segments (chaetotaxy 2, 5, 6, 11-); palpal claw 2-tined.

Legs of moderate length and thickness; from longest to shortest, IV-I-II-III. Chaetotaxy (from coxa to tarsus omitting tarsus I) holotrichous for a dermanyssoid, except for the inclusion of a posteroventral seta on genu IV: I $=2,6,13,13,13,-$; II $=$ $2,5,11,11,10,18 ; \mathrm{III}=2,5,6,9,8,18 ; \mathrm{IV}=1,5,6,10$, 10, 17. Proximal seta of coxa I a strong, blunt spiniform; posterior setae of coxae II and III coarse setiforms; all other coxal 


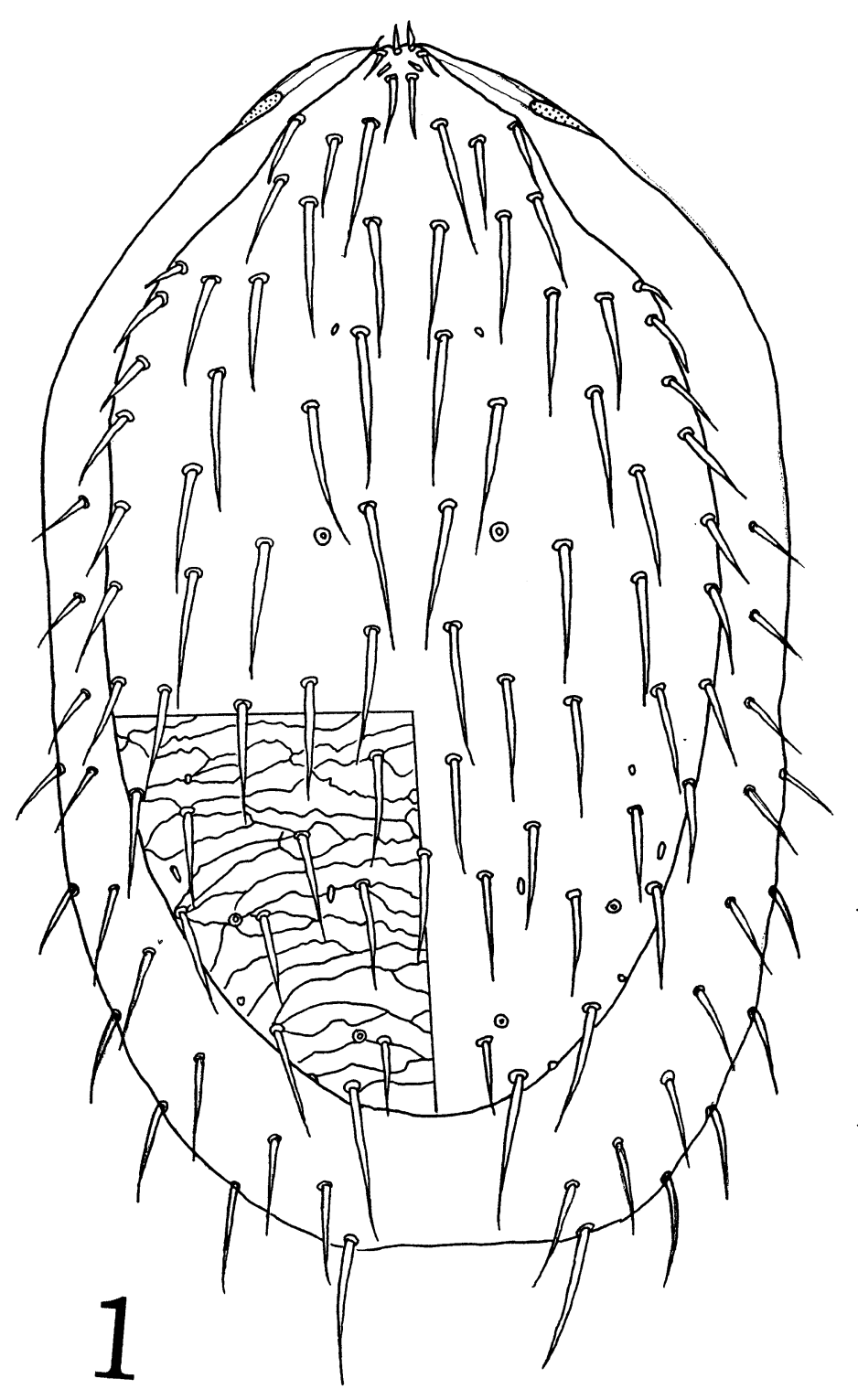

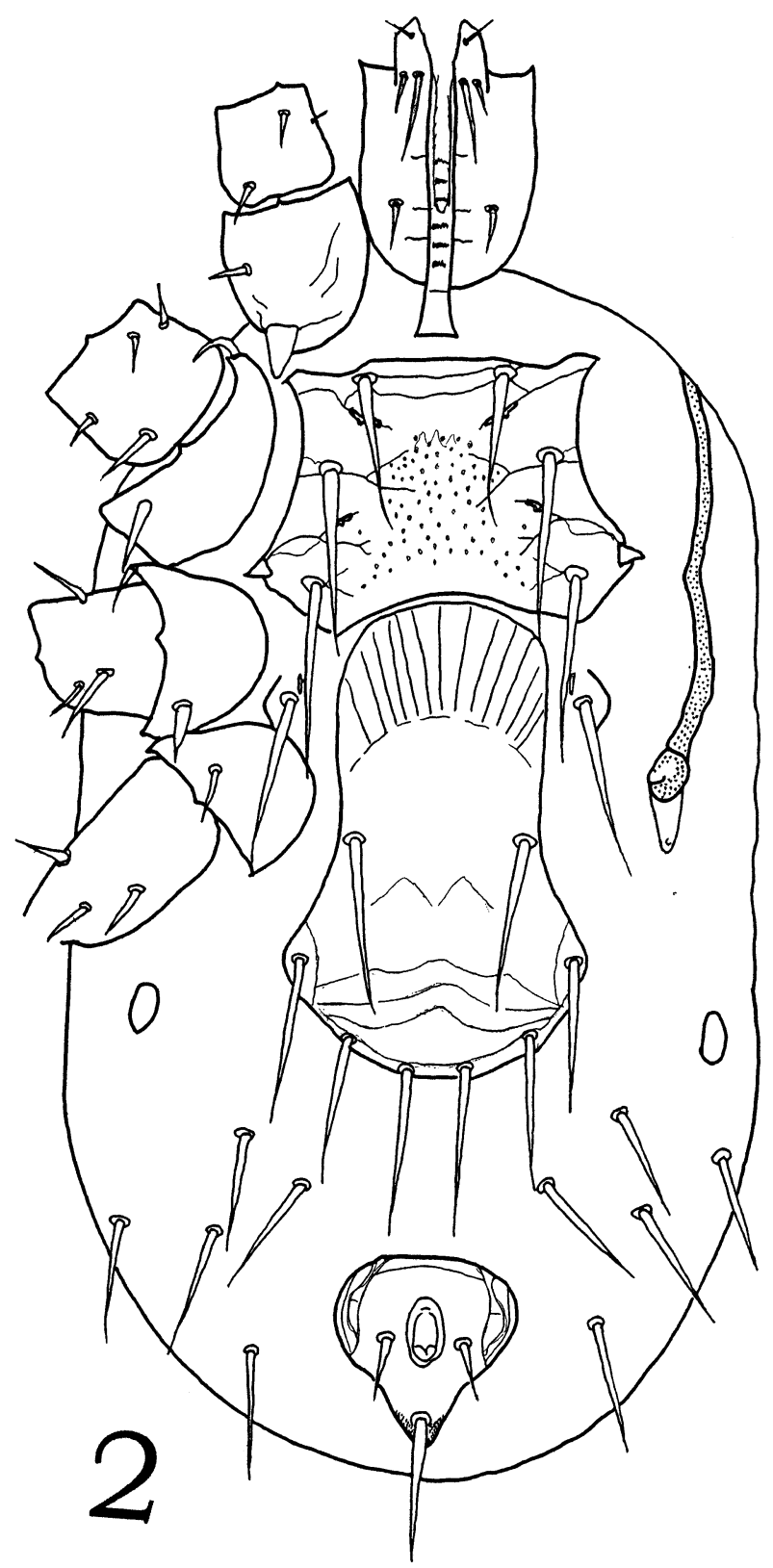

FigURE 1. Laelaps neacomydis, female dorsum.

FIGURE 2. Laelaps neacomydis, female venter. Bar $=100 \mu \mathrm{m}$.

setae simple setiforms; apicodorsal seta femur I, proximodorsal seta genu I, and 2 apicodorsal setae femur II are long and prominent.

Measurements (10 specimens): Dorsal shield length, 508 (492-517); dorsal shield width, 290 (285-297); j5, 72 (70-76); z5, 76 (73-79); J5, 35 (33-36); Z5, 75 (73-78); gnathosomal seta, 21 (19-23); inner hypostomal seta, 33 (31-35); sternal shield length, 98 (95-101); sternal shield width, 122 (119-125); sternal seta 1, 68 (65-72); sternal seta 3, 82 (78-85); sternal seta 4, 83 (79-86); epigynial seta, 78 (72-81); paranal seta, 28 (26-29), postanal seta, 64 (63-67), greatest width anal shield, 79 (77-80), proximal seta coxa I, 23 (22-24), posterior seta coxa II, 34 (32-35), longest apical dorsal seta femur I, 45 (4247).
Male (Figs. 3-4): Overall body size smaller, sclerotization slightly weaker than female. Dorsal shield (Fig. 3) entire, oblong with shoulders, broadest about midlevel; opisthonotum reduced in area; chaetotaxy as in female, including unpaired central opisthonotal seta; glands and pores as illustrated.

Presternal region sculptured as in female. Holoventral shield with genital orifice on anterior margin, at level of insertions for St1, sternal area widest anterior to St3, constricting posteriorly to narrowest at level of St5, strongly expanded posterior to coxae IV; metapodal shields inapparent, possibly subsumed by the lateral expansion of the shield; entire surface reticulate, bearing usual 5 pairs of podosomal setae, with 6 pairs of accessory opisthogastric setae; anal shield and chaetotaxy as in female; unarmed opisthogaster with 3 pairs of submarginal setae. 


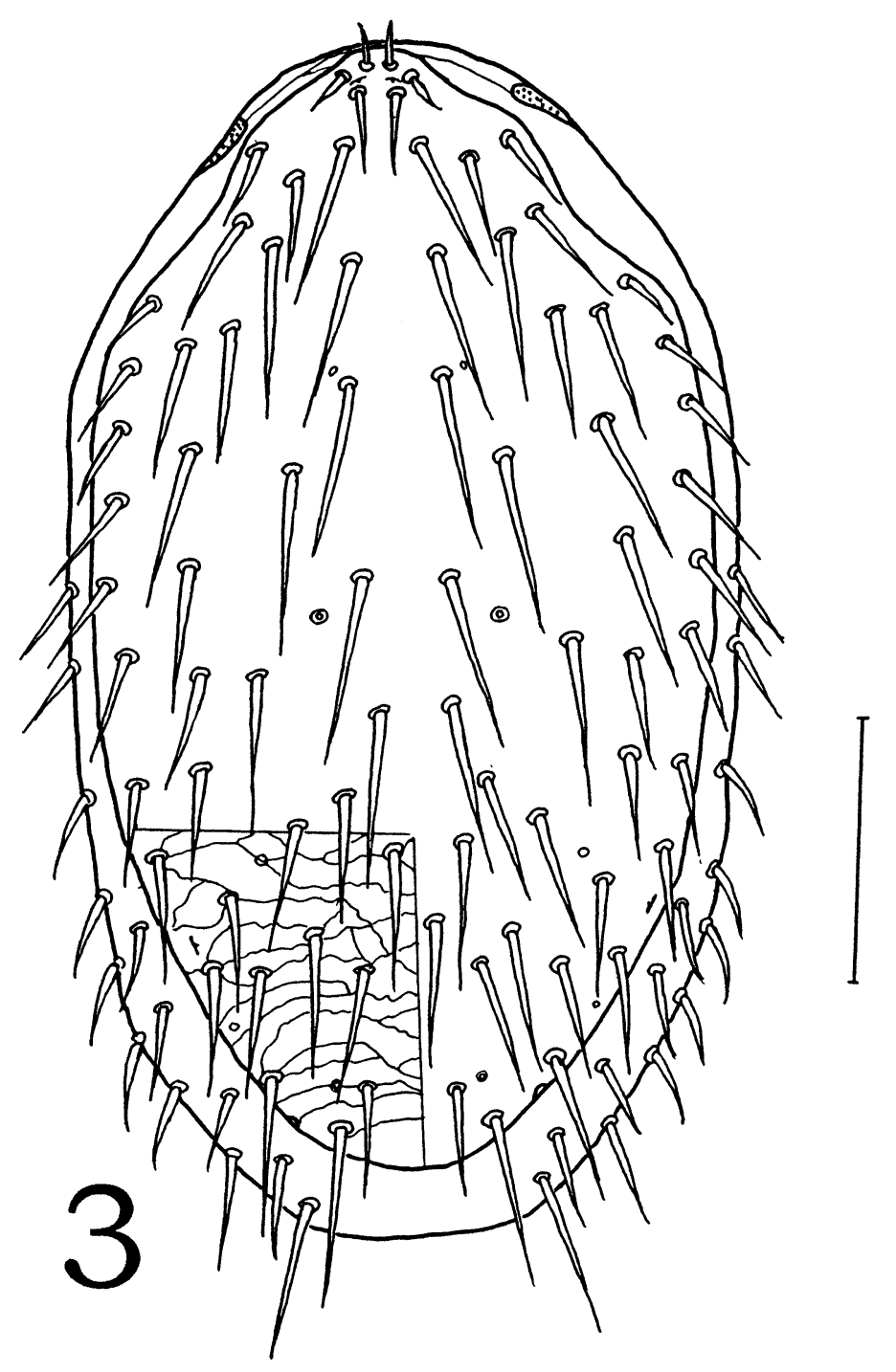

FIGURE 3. Laelaps neacomydis, male dorsum.

FiguRE 4. Laelaps neacomydis, male venter. Bar $=100 \mu \mathrm{m}$.

Epistome as in female. Chelicerae with fixed digit reduced to slender, tapered process (pilus dentilis and dorsal setae inapparent in type series); movable digit modified into grooved, terminally hooked spermatodactyl. Ventral chaetotaxy, tritosternum, and deutosternum as in female.

Leg proportions, chaetotaxy, and ambulacra as in female; proximal seta coxa I, long setiform (unlike spiniform seta of female).

Measurements (3 specimens): Dorsal shield length, 416 (414-420); dorsal shield width, 248 (244-254); j5, 68 (66-68); z5, 74 (71-76); J5, 40 (39-41); Z5, 77 (75-82); gnathosomal seta, 16 (14-18); inner hypostomal seta, 24 (22-26); holoventral shield length, 329 (322-339); holoventral width at level of sternal seta 2, 96 (95-98); sternal seta 1, 62 (59-64); sternal seta 3, 73 (70-75); sternal seta 4, 75 (72-78); sternal seta 5, 69 (65-74); paranal seta, 17 (16-19), postanal seta, 36 (33-38),

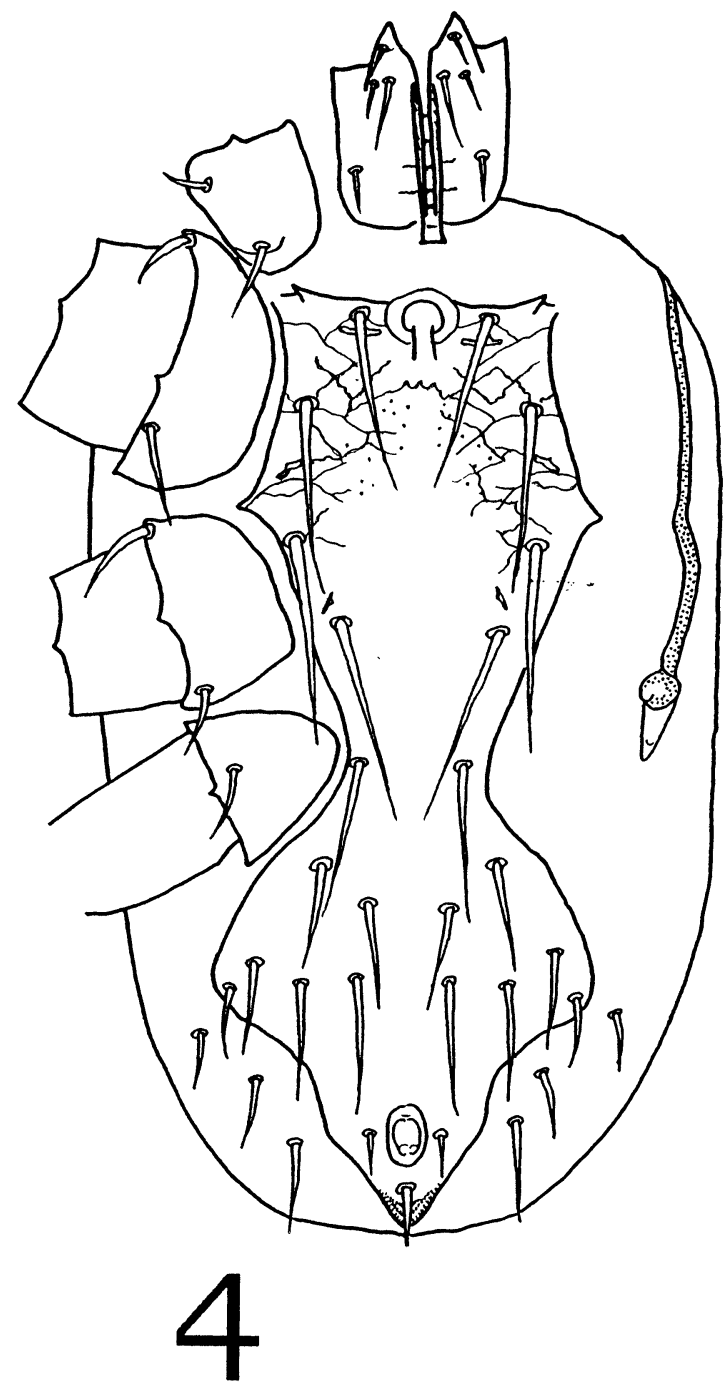

proximal seta coxa I, 30 (27-32), posterior seta coxa II, 34 (33$35)$.

\section{Diagnosis}

Laelaps neacomydis is a small species (female dorsal shield ca. $500 \mu \mathrm{m}$ ) associated with oryzomyine rodents of the genus Neacomys. It is distinguished from all other Laelaps species by the following characteristics: dorsal setation very long, j5 reaching well posterior to the insertion of $\mathrm{z} 5$; a single submedian accessory seta just anterior to $\mathrm{J} 4$; long apicodorsal seta on femur I distinctly longer than long proximodorsal seta of genu I.

\section{Taxonomic summary}

Type host: Neacomys spinosus (Thomas, 1882), Rodentia: Muridae: Sigmodontinae. The specimen (MSB-135531, NK- 
40596) is located in the Division of Mammals, Museum of Southwestern Biology, Department of Biology, University of New Mexico, Albuquerque, New Mexico, and is designated as holosymbiotype (see Frey et al., 1992).

Type locality: Bolivia, La Paz; $13.7 \mathrm{~km}$ (by road) north east of La Reserva, in the Yungas forest at an elevation of $1,830 \mathrm{~m}$ $\left(15^{\circ} 44^{\prime} \mathrm{S}, 67^{\circ} 31^{\prime} \mathrm{W}\right)$.

Type specimens: Eleven slides (holotype, allotype, and 8 paratype females, all collected from the type host on 24 May 1996 and to be distributed as follows: holotype, allotype, and 3 paratype females at the Harold W. Manter Laboratory of Parasitology, University of Nebraska-Lincoln, Lincoln, Nebraska; 2 paratype females at the Instituto Butantan, São Paulo, Brazil; 2 paratype females at the Museu Zoologia, Universidade de São Paulo, Brazil; and 2 paratype females at the Field Museum of Natural History, Chicago, Illinois.

Etymology: The specific epithet of L. neacomydis was taken from the name of the primary host genus.

\section{DISCUSSION}

Mite populations on the host are strongly female biased; males and nymphs are seldom collected. The type series of 10 females is composed of 3 reproductive females carrying larvae, 4 females with eggs, 1 female of undetermined status, and 2 teneral females. Laelaps neacomydis is associated with $N$. guianae and N. spinosus in Amazonian and Andean forests and co-occurs on both these hosts with 2 larger laelapine species, Gigantolaelaps intermedius Furman and L. boultoni Furman and Tipton.

\section{ACKNOWLEDGMENTS}

The survey aspects of this work that provided the specimens were supported by United States National Science Foundation Grants BSR8612329, BSR9024816, DEB9496263, DEB9631295 to S.L.G. and BSR8408923 to T. L. Yates, and BSR8316740 to S. Anderson. The laboratory and museological aspects of this study were provided by a National Science Foundation supplemental grant.

\section{LITERATURE CITED}

ANDERSON, S. 1997. Mammals of Bolivia, taxonomy and distribution. Bulletin of the American Museum of Natural History 231: 1-652.

Frey, J. K., T. L. Yates, D. Duszynski, W. L. Gannon, and S. L. GARDNER. 1992. Designation and curatorial management of type host specimens (symbiotypes) for new parasite species. Journal of Parasitology 78: 930-932.

Furman, D. P. 1972. Laelapid mites (Laelapidae: Laelapinae) of Venezuela. Brigham Young University Science Bulletin, Biological Series 17: $1-58$

GARDNER, S. L. 1996. Appendix 6: Field parasitology techniques for use with mammals. In Measuring and monitoring biological diversity: Standard methods for mammals, D. E. Wilson, F. R. Cole, J. D. Nichols, R. Rudran, and M. S. Foster (eds.). Smithsonian Institution Press, Washington, D.C., p. 291-298.

- AND M. L. CAMPBELl. 1992. Parasites as probes for biodiversity. Journal of Parasitology 78: 596-600.

Gettinger, D., F. Martins-Hatano, M. Lareschi, and J. R. Malcolm. 2005. Laelapine mites (Acari: Laelapidae) associated with small mammals from Amazonas, Brazil, including a new species from marsupials. Journal of Parasitology 91: 45-48.

Lindquist, E. E., AND G. O. Evans. 1965. Taxonomic concepts in the Ascidae, with a modified setal nomenclature for the idiosoma of the Gamasina (Acarina: Mesostigmata). Memoirs of the Entomological Society of Canada 47: 1-64.

WiLSON, D. E., AND D. M. ReEDER. 1993. Mammal species of the world A taxonomic and geographic reference. Smithsonian Institute, Washington, D.C., 1207 p. 